\title{
On the Problem of the Influence of Soviet Demographic Policy on the Urban Population of Bashkortostan in 1930s-1950s
}

\author{
Svetlana Vitalievna Shalagina ${ }^{1}$, Ramil Saphievich Istamgalin ${ }^{1}$, Inna Petrovna Lobankova ${ }^{1}$, Elvira Ramalievna \\ Iseeva $^{1} \&$ Tatiana Pavlovna Kotova ${ }^{1}$ \\ ${ }^{1}$ Ufa State University of Economics and Service, Russian Federation \\ Correspondence: Svetlana Vitalievna Shalagina, Chernyshevskiy str., 145, Ufa, 450078, Bashkortostan, Russian \\ Federation.
}

Received: January 24, 2015 Accepted: May 5, 2015 Online Published: July 30, 2015

doi:10.5539/ass.v11n19p185 URL: http://dx.doi.org/10.5539/ass.v11n19p185

\begin{abstract}
The paper studies the urban population of the Bashkir Soviet Autonomous Republic in 1930-1950s in a territorial and regional point of view. In the paper, the authors discover the character and features of Soviet architectural policy in Bashkortostan. Besides, the authors find out general historical regularities and development trends of reproduction in Russia and pronounced regional peculiarities. The authors analyze the specific development of economic reforms in Soviet Union and their political grounds. Moreover, the authors study the sources and channels of population growth in Bashkortostan in the context of state reforms in Russia.
\end{abstract}

Keywords: population, migration, urban population, regional geographical aspect, social development, political process, urbanization

\section{Introduction}

Social stability is determined by the deliberateness of political and social decisions of the government. One of the important factors of efficient relations in a country is a detailed population policy with a good theoretical basis. We consider such policy as a succession of administrative and economic measures which have a technological influence on people's natural mechanic behaviour.

The goal of the paper is to study historical regularities in the spatial distribution of population. This is a complex interconnection between the elements of social development. The goal demands universal methods and approaches.

\section{Methods}

The basic primary data of events described in the paper corresponds to the data of the Central Historic Archives of the Republic of Bashkortostan and the Central State Archives of Public Associations of the Republic of Bashkortostan.

In this paper, the historical and demographic data are analyzed on the basis of the problem principle, the chronological method, the method of historical simulation, classification and the way the common correlate with the particular and the fact correlates with the theory. The information about real population size was recovered by the mathematical treatment of resources and historical statistical computation. The researchers took into account the specificity of interval characteristics while studying certain processes in population and computed the total intensity of political and economic events that took place in the USSR in the middle of the previous century. Then the authors conducted a comparative analysis and stocktaking and found relative values i.e. coefficients. Besides the above methods, the authors used such methods as rank correlation (the ratio between the final component and the closeness (remoteness) of his elements); the dispersion- correlation method (averaging with bipolar (territorial and geographical) coefficients).

\section{Findings}

The data of urban population of Bashkortostan clearly demonstrate that:

1) In the previous century, cities were built on state and economic grounds and with the necessity to solve socially important political problems. 
2) The urban population of the Autonomous Republic has the multinational composition and the different size of national groups represented in it both in general and in certain settlements. All this bears an imprint of the region's history and we can see the uneven development of industry from the territorial and geographical point of view.

3) Mainly heavy industry developed, and it required additional labour reserves. Thousands of people of various nationalities came to the leading construction sites. They determined and changed the national structure of the Republic.

The grandiose goals to create an industrial complex caused the rapid growth of productive forces and determined the objective character of urbanization unprecedented for Bashkiria including the growth of cities and urban population. Besides, these goals changed the characteristics of the population, such as the place, conditions and quality of life.

\section{Discussion}

Many today's political, economic and socio-spiritual problems both traditional and new cannot be studied properly without considering the aspect of population. Western scientists paid a special attention to the demographic laws of social development (Glicketal, 2003; Light, 2004, pp. 705-737; Wallerstein, 1974). British demographers studied deeply the regularities of migration behaviour (Ravenstein, 1885, pp. 167-235). American researchers contributed much to the theory of migration processes (Bourdieu and Richardson, 1986; Massey and Douglas, 1989, pp. 383-414; Todaro, 1980). On the one hand, they detected factors that attract and push out people in mechanical reproduction of population (Lee, 1966, pp. 47-57; Piore, 1979). On the other hand, they brought migration relations into correlation with the specificity of rural and urban economy (Todaro, 1980) and studied the main motives of people's migration behaviour (Wallerstein, 1989; Zelinsky, 1971, pp. 219-249).

Russian scientists mostly assess population through the territorial and regional peculiarities of country's social structure and through state interests (Borisov, 1999; Horev, 1981; Galiullina, 2012, pp. 191-193). Moreover, there are such special lines of research as migration mobility (Rybakovsky, 1976; Urlanis, 1976) and the migration behaviour of different socio-demographic and territorial groups of population (Volkov, 1999, pp. 42-49). Lately, the research of urban population from the historical viewpoint has greatly enhanced in Russia (Blum \& Zakharov, 1997; Krivosheev, 1995). However some aspects of population's development in the middle of the $20^{\text {th }}$ century demand a more detailed study.

Urbanization is one of the most important development lines of political and economic relations in a country. In Russia, this process started its active growth from the beginning of the $19^{\text {th }}$ century. The Soviet period is characterized by planned and tactically estimated urban extension. Urbanization directly affected Bashkiria as well. In the 1930s, the sectoral development of Bashkortostan was based on the development of oil and gas fields, oil refineries and transportation points for resources. The industrial development promoted the increase of population size in urban areas. The employment in oil sector, iron and steel industry, chemical industry and gold-mining actively augmented urban population in the region. Thus by the end of 1930s, the real conditions for changes in population concerning sex, age, nationality, reproduction and living conditions were created in Bashkortostan. The architectural policy was also changed. All the enumerated political and economic components determined the uneven (from the territorial and geographical point of view) development of urban system in the Republic and a sharp growth of cities and urban population in comparison with previous years. Cities grouped by their administrative and territorial status had certain peculiarities in population size and national composition.

On January 17, 1939, there were 329,363 residents in urban settlements of republican subordination. This makes up $10.4 \%$ of the whole population of the Bashkir Autonomous Republic (Ufa - 7.9\%, Beloretsk - 1.3\%, Sterlitamak $-1.2 \%$ ) and $60.95 \%$ of the whole urban population of the region. The increase of population in cities of republican subordination (for 13 years, according to the census of 1939) was 181,856 people, i.e. the growth was $123.2 \%$. The increase of urban population was caused by the programme of industrial construction in the second five-year plan approved by the $17^{\text {th }}$ Congress of the All-Union Communist Party of the Bolsheviks (Shalagina \& Kazantseva, 2014, pp. 2310-9319). The programme included the building of an automobile plant in Ufa, a new group of oil refineries in Ufa and Sterlitamak and further development of mining and metallurgy in Beloretsk (Shalagina \& Kazantseva, 2014, pp. 2310-9319). The capital deserves a special attention among the urban settlements of republican subordination. The population of Ufa grew from 102,241 people in 1926 to 250,011 people in 1939 . The increase was $144.5 \%$ or $11.1 \%$ of average annual increase. For the period that we have data about the population of Ufa, this increase is the highest. If the increase of capital population is compared with the increase of population in nearest cities with similar national economic significance, then the 
index of population increase of Ufa in 1926-1939 is higher. Particularly, the urban population of Ufa grew by $144.5 \%$, the population of Kazan grew by $124.4 \%$, the population of Kuybyshev grew by $122.2 \%$ and the population of Chkalov grew by $40.3 \%$. The rapid grow of capital population had not only internal sources. It was also replenished by growing oil industry in the city. For example, in 1939, in accordance with the Decree of the Council of People's Commissars and the Central Committee of the All-Union Communist Party of Bolsheviks "On the development of new oil regions", The People's Commissariat of Oil Industry of the USSR sent about two thousand builders from Baku and Grozny to the capital of Bashkiria. The People's Commissariat of Heavy Industry of the USSR sent builders and fitters from Moscow Metrostroy to Ufa (Shalagina \& Kazantseva, 2014, pp. 2310-9319). The cities of regional subordination in Bashkiria numbered 48,291 people. This was $1.5 \%$ of the total population of the Republic and 9\% of total urban population of Bashkiria. In the beginning of 1939, the total number of residents in urban-type villages was 162,625 people. According to the census of 1926 , the number of residents in similar settlements was 58,789 people. The increase was 103,836 people, i.e. $176.6 \%$, or by 2.8 times. In 1926, the population percentage of urban-type villages in the total population of Bashkir Autonomous Soviet Socialist Republic (BASSR) was 2.3\% while in 1939 it was 5.1\%. Territorial points of oil extraction and transportation showed the highest indices of population growth. These points appeared and became urban because they included city-forming industrial complexes. This was made according to the Decree "On the development of new oil regions" released by the Council of People's Commissars of the USSR and the Central Committee of the All-Union Communist Party of Bolsheviks in March 1939 (Shalagina \& Kazantseva, 2014, pp. 2310-9319).

By 1939, the development of population in Bashkir Republic was based on specific points that differed from opening up other lands: 1 . In the $20^{\text {th }}$ century, cities in the Republic were built with state and economic justification. It required solving socially important political and industrial problems. This was reflected in resolutions of congresses, conferences and plena of the Communist Party and in decrees of the Soviet government; 2. Urban population increased due to labour resources invited from rural areas and other regions of the USSR. That is the external source but not natural movement prevailed in the growth of urban population.

In the next years, the history of Bashkiria was greatly influenced by migration. Firstly, the migration caused a tremendous negative migration balance connected with military conscription and mobilization. The Soviet government took drastic measures to consolidate manpower and technical resources to resist the enemy. The hostilities that took place both in the Soviet Union and in the Western Europe were catastrophic. They determined the inevitable arrest of peaceful and so more efficient development of the country. The war had a serious negative influence on the quantitative changes in population (Krivosheev, 1995) including the population of Bashkiria. The forced mass mobilization and military conscription reorganized their reproduction in subsequent decades.

The evacuation of people from front-line areas to the Bashkir Republic was no less important direction of the region's development. This process was based on the Decree "On the creation of the Evacuation Council" released by the Council of People's Commissars of the USSR and the Central Committee of the All-Union Communist Party of Bolsheviks June 24, 1941. N. M. Shvernik was appointed chairman of this Council. This measure was dictated by "... the defence interests of the country and resulted from an urgency to concentrate forces on the strategic goal: to move major human and technical resources from dangerous areas to the rear" (Bikmaev, 2000).

The system accounting of population evacuated to the Republic began with the Order \#74 released by the Council of People's Commissars of Bashkiria February 3, 1942. In accordance with the Order \#117/r released by the Council of People's Commissars of the USSR January 5, 1942, the Order \#74 instructs the Migration Department to perform a new account of people evacuated to the Republic (Shalagina \& Kazantseva, 2013, pp. 2310-9319).

The statistical data of the postwar years indicate that people who became permanent residents of the cities of the Republic prevailed considerably. Particularly, 30,473 citizens were registered in the Republic by February 1, 1947. 6,000 of them lived in the countryside (Shalagina \& Kazantseva, 2013, pp. 2310-9319). So, the content of war migrants in the urban area of the Republic was 24,473 people or $80.3 \%$ of their total number. In the summer of 1948 , the number of earlier evacuated people was 29,430 people, and $80 \%$ of them were urban residents (Shalagina \& Kazantseva, 2013, pp. 2310-9319). 
Table 1. The population of Bashkiria in 1939-1945

\begin{tabular}{|c|c|c|c|c|c|c|}
\hline Settlement & $\begin{array}{l}1939 \text {, thous. } \\
\text { people }\end{array}$ & $\begin{array}{l}\text { 1941, thous. } \\
\text { people }\end{array}$ & $\begin{array}{l}\text { 1942, thous. } \\
\text { people }\end{array}$ & $\begin{array}{l}\text { 1943, thous. } \\
\text { people }\end{array}$ & $\begin{array}{l}\text { 1944, thous. } \\
\text { people }\end{array}$ & $\begin{array}{l}\text { 1945, thous. } \\
\text { people }\end{array}$ \\
\hline City & 540.3 & 604.4 & 737.1 & 773.2 & 782.7 & 712.0 \\
\hline Village & 2618.7 & 2631.9 & 2526.8 & 2380.0 & 2317.7 & 2151.0 \\
\hline Total & 3159.0 & 3236.3 & 3263.9 & 3153.2 & 3100.4 & 2863.0 \\
\hline
\end{tabular}

The Second World War made its changes in social development and seriously influenced the natural and mechanical reproduction of population.

Table 2. The natural reproduction of urban population in Bashkiria (1941-1945)

\begin{tabular}{llll}
\hline & \multicolumn{2}{c}{ Rate for 1,000 of urban residents } \\
& Fatality & Natality & Natural increase \\
\hline 1941 & 26.6 & 19.3 & +7.3 \\
January, 1942 & 28.0 & 24.2 & +4.0 \\
December, 1942 & 11.2 & 19.3 & -8.1 \\
January, 1943 & 13.2 & 20.3 & -7.1 \\
December, 1943 & 14.2 & 20.5 & -6.3 \\
1944 & 9.1 & 18.3 & -9.2 \\
1945 & 12.8 & 11.0 & +1.8 \\
\hline
\end{tabular}

Being one of the most difficult and heroic pages of our history, it created severe and extreme conditions, disturbed the natural evolution of population and changed the main components of reproduction including the surge in the number of children who lost their parents at the front.

The military conflict of 1939-1945 had tragic and at the same time diverse results for Russia. The war brought an enormous damage to the economic development of the country in general. Besides, it should be stated that regions that avoided hostilities had a certain advantage. Particularly, Bashkiria got an opportunity to become later one of the highly-developed industrial centers of the country because of heavy industry which was moved there from the occupied areas of the USSR. This fact was the one that affected the population of the region. Many characteristics of today's country originate from the 1940s. As we have already noted, the rapid postwar development of industry in Bashkiria required inviting new labour resources who not only increased the number of workers but also promoted the growth of urban population.

The mechanical increase of urban residents had several sources in those years. The first and the most important one was that people moved from villages to urban areas.

From 1946, an organized recruitment of manpower was performed in the regions of Bashkiria. As a result, 23,816 people were sent to build electric power stations, 1,196 people were sent to the plants of such cities as Magnitogorsk and Ashi. More than 120 people were sent to the plants of Beloretsk, and 100 people were sent to the industry of 4444 were sent to the plants of Beloretsk, and 100 people were sent to the industry of Tukan. 52 people were invited to Ufa, 10 people were sent to Belebey and 60 people were sent to Chernikovsk. The mines of towns Sibay, Tubinsk, Mindyak and Uchaly received 14,468 people, and 128 people were sent to the soda plant of Sterlitamak. The peat plants of the Republic received 35,646 people from the regions. Altogether, 73,034 people were involved in labour service for the year under review, and 19,610 of them were urban residents (CSAPO RB. F. 122. Inv. 84.C. 201. L. 42). In coefficient expression, 28 peoples from every 1,000 of rural dwellers and 27 people from every 1,000 of city dwellers were liable to the mobilization. As a result of active mobilization, the increase of rural population was 3\% from 1946 to 1959 . The annual mechanical loss of rural population was $1 \%$. The second line is the active work of Komsomol organizations to invite young people to the main construction projects of the country. By the call of the Bashkir Komsomol, more than 5 thousand young people came to the plants of Ufa, Sterlitamak and Ishimbay in 1946-1948. By the call of the Regional Committee of Bashkiria, the Komsomol of the Republic sent more than 2 thousand young people to the oil fields of Ishimbay. In 1955, The Central Committee of the Party and Soviet government made decisions "....on the fundamental improvement of construction by the development of structural precast concrete industry". After that 
the Komsomol of Bashkiria sent more than 3 thousand young people to the plants of construction industry. May 18, 1956, The Central Committee of the Communist Party of the Soviet Union (CPSU) and the Council of Ministers of the USSR released the Appeal "To all Komsomol organizations and all Soviet young people". In the document, they noted that "A great work was done in the Eastern part of the country during the Soviet period. New cities and big plants appeared there. Many new workers will be required for new great plans. The Party and the government appeal to all Komsomol organizations and to all Soviet young people to chose among them 400-500 thousand young boys and girls who would begin building new plants and hydroelectric power stations in 1956-1957" (CSAPO RB. F. 122. Inv. 84. C. 201. L. 42). In June 1957, the Central Committee of the Communist Party of the Soviet Union (CPSU) and the Council of Ministers of the USSR released the Decree "On the public appeal for young people to the most important construction projects of the country in the Eastern and Northern regions of the USSR". The government's appeal encouraged youth initiatives aimed at fulfilling the plans of national economy. During 1956-1957, more than 5 thousands young boys and girls joined the top-priority projects of the Bashkir Republic. About 1.5 thousands Komsomol members went from Bashkiria to Eastern Siberia to built hydroelectric power stations. The Komsomol of Baskiria developed new lands not less active. For the period 1958-1960, more than 4 thousand young people came to chemical industry by the order of the Komsomol. Altogether, more than 15 thousand young workers and clerks came to build chemical plants. The third line is special migrants. These people were taken from Western Ukraine and sent to Bashkiria before the war. As a rule, they settled in rural area. Soviet ethnic Germans underwent a more serious movement. They numbered about 13 thousand people in labour armies. The majority of resettled ethnic Germans worked in the factories of the Republic. At the end of the war, people from the Crimea were moved to Bashkiria according to the Decree of the State Defence Committee. After the war, more than 2 thousand members of the Vlasov's army were also moved to the Bashkir Republic. The majority of them worked in the oil industry of Ufa and Tuymazy (CSAPO RB. F. 122. Inv. 84. C. 201. L. 42). The data about special migrants settled in Bashkortostan are incomplete and fragmentary. A detailed account and analysis of this group of people does not seem possible today. Nevertheless, the biggest part of them was apparently used in labour-intensive industries. For example, in the oil-and-gas industry of Tuymazy there were 4,002 workers including 659 repatriates (16.5\%), 572 special migrants (14.3\%), 411 former prisoners (10.3\%), 1,754 civilians (43.8\%). 1,200 people of the special contingent worked in the paper mill of Krasny Klyuch; 3,800 people worked in oil industry including 1,300 in Ufa, 625 in Sterlitamak, 1,375 in Ishimbay and 500 in Tuymazy. By 1951, there were 18,960 migrants in the Republic in all. This number gradually went down afterwards. By 1952, the special contingent consisted already of 13,085 people or $69 \%$ of their number that was in 1951. In 1955 they numbered 9,815 people (CSAPO RB. F. 122. Inv. 84. C. 201. L. 42) or $75 \%$ of their number that was in 1952. So, their number almost halved as compared to 1951 . Besides special migrant applied in labour-intensive industries, cities had camp points (Sterlitamak, Ufa and Salavat) and a labour camp in Tuymazy. In the beginning of 1949, this labour camp included 5,578 prisoners, but almost a year later their number decreased up to 830 people or by $85 \%$ (CSHA RB. F. 933. Inv. 6. C. 971. L. 15). The number of special migrants and the prisoners of special camps went down considerably because of the amnesty granted by the Soviet government.

The next direction of external mechanical increase of urban population (not weighty in scale but considerable from the historical point of view) was the return migration of Soviet citizens from abroad to Bashkiria. By the beginning of 1949, their total number in the Republic was 239 people, while 233 of them or $97.5 \%$ lived in central cities. Four of them came from France and lived in Ufa and 229 people came from China. There were 37 reemigrants in Ufa, 38 in Chernikovsk, 54 in Sterlitamak, 5 people in Davlekanovo and 99 people in Beloretsk (CSHA RB. F. 933. Inv. 6. C. 971. L. 15).

By 1950, as it was said above, the mechanical movement of people from villages and other regions of the country to the top construction projects of postwar time promoted the recovery of percentage balance of reproductive sex-and-age groups. At the same time, by 1946, the percent of mechanical increase of urban population was $7.1 \%(55,981$ people $)$ of the total number of city residents. The total increase of population was $7.5 \%$. From 1946 to 1947, the mechanical movement of people to the urban areas of the Republic was 35,600 people or $4.3 \%$ of the total number of urban population. In 1947, the number of people who moved to cities was 56,210 or $6.6 \%$ of the number of urban dwellers. This year, the total increase of

Urban population was $8.3 \%$. In 1948, the increase of urban population as compared to the previous year was 32 thousand people or $3.7 \%$ of the urban population. Then we can see a rapid decrease of the total increase of urban population. From 1949 to 1950 , the urban population grew by 24,300 people or only by $2.7 \%$. 
Table 3. The population of Bashkiria in 1946-1950

\begin{tabular}{llllll}
\hline & \multicolumn{5}{l}{ Population, thous. people } \\
& 1946 & 1947 & 1948 & 1949 & 1950 \\
\hline Urban population, total & 782.7 & 821.7 & 853.7 & 883.7 & 908.0 \\
Total population & 2790.0 & 2845.0 & 2688.0 & 2930.0 & 2975.0 \\
\% of the urban population in the total population of Bashkiria & 28.1 & 28.9 & 31.8 & 30.2 & 30.5 \\
\hline
\end{tabular}

As Table 2 shows, the increase of both urban and rural population of Bashkortostan in 1946-1950 was greatly influenced by the war catastrophe. During these years, the number of residents increased slightly and did not reach the level of the world demographic reproduction.

During 1950-1953, the urban population increased by 33,800 people or $36 \%$ of the total number of city residents. The mechanical movement made up $1.7 \%$. From 1953 to 1954 , the urban population grew by 83,100 people. The mechanical movement made up 58 thousand people or $5.8 \%$ of the total number of city residents.

By 1955 , the total increase of the urban population was 51,300 people or $4.8 \%$. The mechanical movement grew by 26,200 people or $2.5 \%$. In 1956 , as compared to the previous year, the urban population in Bashkiria increased by 52,800 people. By 1957 , the urban population increased by 53,600 people, and the mechanical movement was $2.5 \%$ (28,700 people). For the period 1957-1959, people's mechanical movement to cities was equal to 63 thousand people (CSHA RB. F. 933. Inv. 6. C. 971. L. 15).

Table 4. The urban population of Bashkiria in 1954-1959

\begin{tabular}{lllllll}
\hline & \multicolumn{6}{l}{ Population, thous. people } \\
& 1954 & 1955 & 1956 & 1957 & 1959 \\
\hline Urban population, total & 1007.3 & 1058.6 & 1111.4 & 1165.0 & 1280.719 \\
\% of increase from the previous period & - & 105.1 & 105 & 104.8 & 110 \\
\hline
\end{tabular}

In conditions created by internal and external factors in Bashkiria, the increase of the urban population was 498 thousand people or $63.6 \%$ in 1946-1959. As for the mechanical and natural movement of people in the general reproduction of urban population, the first component prevailed considerably in the first decade after the war. In 1946, the mechanical reproduction of city residents made up $94.9 \%$, while the natural reproduction had $5.1 \%$. In 1947, these indices were $91.5 \%$ and $8.5 \%$, respectively. From 1954, a sharp turn began. The share of mechanical population movement in the total increase of the urban population fell and made up $61.7 \%$, while the natural reproduction had $38.3 \%$. In 1955 , this ratio was $51.0 \%$ : 49.0\%. In 1956 it was $52.5 \%$ : $47.5 \%$. In 1957 it was $53.5 \%$ : $46.5 \%$. In $1958-1959$, the natural reproduction of the population grew and made up $82.0 \%$ of the total increase of the urban population. As a result, the share of mechanical movement was only $12 \%$.

So, by the end of 1950s, the priority in the reproduction of urban residents to a large degree passes to the natural movement of population.

The performed analysis of numerical reproduction of the urban population confirmed that the natural increase of urban residents in the postwar period with their considerable lag relative to the mechanical movement was an effect of not only many wars of the first half of the $20^{\text {th }}$ century but also the active policy of industrialization and the growth of industrial potential of the country which required additional labour resources. The heavy industry of Bashkiria had the greatest need for manpower. Thus both rural residents employed by the organized recruitment and volunteers who came from other regions of the country by the appeal of the Party and the Komsomol worked in the heavy industry of the Republic. It should be noted that since the late 1950s this trend of urban population growth gradually lost ground. By 1959, the ratio of natural and mechanical reproduction of the urban population equalized. This was caused by the end of active industrialization in Bashkortostan. In these years, they created an industrial structure that met the requirements of development of the efficient country and its population.

In the period under study, the indices of urban population in Bashkiria and in the whole USSR changed in a complicated and contradictory manner. The system of political regime which controlled, corrected and linked all social relations was the most important circumstance. It determined and changed the process in population. Te 
society was being rebuilt during the whole period under study. This rebuilding was both revolutionary and evolutionary and led to large-scale changes in the number and distribution of urban residents in the Republic. Active urbanization was followed by changes in the size of population, the place and conditions of living and social status. So, the history of population has both horizontal (territorial) and Vertical (social status) indices. The main sources of population growth in Bashkortostan were: 1. Active industrialization; 2. The change (expansion) of urban areas; 3 . The intensive creation of new urban settlements; 4 . The natural increase of population in cities (except the war time); 5. Migration from other parts of the country; 6 . The character of collectivization which promoted the movement of rural dwellers to the cities of the Republic.

The period under study was the time of uneven, complex and contradictory processes in society and reproduction. The development of Bashkir society presupposed qualitative changes in all life spheres. As a result, such timely channel of the social structure as the production of man himself was also changed appreciably due to the political predetermination of the development of the Soviet state.

Today's indices of urban population size and distribution bear the imprint of peoples' history and are in a large measure determined by the stages and characteristics of population processes that took place in the past. The ambiguity of these processes concerning their deepness and character equal the complex but interesting moments of modern political and economic history of Russia and its regions.

\section{Conclusion}

The study of settlement processes in the urban population of Bashkortostan has a great practical importance. The peculiarities of regional development of urban population are interpreted with personification. At the same time, the analysis of urban population history in the Republic allows finding a row of All-Russian regularities not described in the macro-historical analysis. The materials presented in the paper can be used in further advanced, detailed and interdisciplinary study of population history of Russia and Bashkortostan.

\section{References}

Bikmaev, M. I. (2000). Bashkortostan during the Second World War: 1939 - 1945. Ufa, Russia.

Blum, A., \& Zakharov, S. (1997). The Demographic history of the USSR and Russia in the mirror of the generations, Population and society. Moscow, Russia: INF. Bulletin of the Center for demography and human ecology of the Institute of economic forecasting of the Russian Academy of Sciences, 17.

Borisov, V. A. (1999). Demographics. Moscow, Russia: Publishing house NOTA BENE.

Bourdieu, P., \& Richardson, J. (1986). Handbook of theory and research for the sociology of education. The forms of capital. New York, NY: Greenwood Press.

Central state archive of public organizations of the Republic of Bashkortostan (CSAPO RB). F. 122. Inv. 84. C. 201. L. 42.

Central state historical archive of the Republic of Bashkortostan (CSHA RB). F.933. Inv. 6. C. 971. L. 15.

Galiullina, S. (2012). Normative and legal regulations of the institution of trusteeship of public schools of the Russian empire. Theory and practice of public development: Scientific Journal, 5, 191-193.

Glick, J., White, E., \& Michae, J. (2003). The Academic Trajectories of Immigrant Youths: Analysis Within and Across Cohorts. Scientific Journal Demography, 40, 759-783. http://dx.doi.org/10.1353/dem.2003.0034

Horev, B. S. (1981). The resettlement of the population. Moscow, Russia: Statistics.

Krivosheev, G. F. (1995). The Great Patriotic war. Facts and figures about the Education. Moscow, Russia: Education.

Lee, E. (1966). A Theory of Migration. Demography, 1, 47-57. http://dx.doi.org/10.2307/2060063

Light, D. (2004). From Migrant Enclaves to Mainstream: Conceptualizing Informal Economic Behavior. Scientific journal Theory and Society, 6, 705-737. http://dx.doi.org/10.1023/B:RYSO.0000049193.32984.c2

Massey, \& Douglas, S. (1989). International migration and economic development in comparative perspective. Population and Development Review, 14, 383-414. http://dx.doi.org/10.2307/1972195

Piore, M. (1979). Birds of passage. Migrant lab our and industrial societies. New York, NY: Cambridge University Press. http://dx.doi.org/10.1017/CBO9780511572210

Ravenstein, E. G. (1885). The Laws of Migration. Journal of the Statistical Society of London, 2, 167-235. http://dx.doi.org/10.2307/2979181 
Rybakovsky, L. L. (1976). The Territorial settlements of the RSFSR. Moscow, Russia: Statistics.

Shalagina, S., \& Kazantseva, E. (2013). Certain aspects of evacuation to the republic of Bashkortostan in the period of the great patriotic war. Scientific Journal Scientific Potential, 2(93-97), 2218-7774.

Shalagina, S., \& Kazantseva, E. (2014). The influence of the economic policy of the soviet state on the amount of city population of Bashkortostan in 1930s (a territorial and regional analysis of the issue). Scientific journal Society, 2(7-13), 2310-9319.

Todaro, M. (1980). Internal migration in developing countries: A survey. Population and economic change in developing countries. Chicago: University of Chicago Press.

Urlanis, B. C. (1976). Population. Moscow, Russia: Statistics.

Volkov, A. G. (1999). Methods and problems of demography. Scientific journal Statistics, 8, 42-49.

Wallerstein, I. (1974). The Modern World System, Capitalist Agriculture and the Origins of the European World Economy in the Sixteenth Century. Academic Press.

Wallerstein, I. (1989). The Modern World-System, vol. III: The Second Great Expansion of the Capitalist World-Economy, 1730-1840's. San Diego: Academic Press.

Zelinsky, W. (1971). The Hypothesis of the Mobility Transition. Geographical Review, 61, 219-249. http://dx.doi. org/10.2307/213996

\section{Copyrights}

Copyright for this article is retained by the author(s), with first publication rights granted to the journal.

This is an open-access article distributed under the terms and conditions of the Creative Commons Attribution license (http://creativecommons.org/licenses/by/3.0/). 